\title{
Legal Support for Assessing the Civil Servants Professionalism in the Context of Modern Socio-Economic Development
}

\author{
Submitted 06/06/20, $1^{\text {st }}$ revision 07/07/20, $2^{\text {nd }}$ revision 27/08/20, accepted 15.09/20 \\ Ryabova M.V. ${ }^{1}$, Koroleva S.V. ${ }^{2}$, Tutinas E.V. ${ }^{3}$, \\ Zavgorodnyay L.V. ${ }^{4}$, Millerov E.V. ${ }^{5}$, Kavelina O.G. ${ }^{6}$ \\ Abstract:
}

\begin{abstract}
Purpose: The purpose of the article is to examine the problem of legal regulation of assessing the civil servants professionalism, taking into account the economic development of Russia.

Design / Methodology / Approach: The empirical basis of the study is international legal acts, regulatory legal acts of the current administrative legislation, including federal laws and acts of the Government of the Russian Federation. The methodological basis of the research is mainly made up of general scientific methods, analysis, synthesis, induction, deduction.

Findings: The authors analyzed the norms of international and national law on civil service issues, revealed the influence of the existing economic relations on the efficiency of civil servants. The authors came to the conclusion that it is necessary to improve the methodology for determining the effectiveness of the work of civil servants, taking into account the positive foreign experience of public administration.

Practical Implications: As a result of the analysis of foreign and reporting experience, the authors have developed recommendations for improving the mechanism for assessing the professionalism of a civil servant and proposed changes to the current legislation.

Originality / Value: There is a need to reform modern approaches to solving issues, taking into account the trend of digitalization of the sphere of public administration and the impact of emergencies, including epidemics and others on this process, as well as the introduction of telecommuting for civil servants.
\end{abstract}

Keywords: Civil service, assessment of professionalism, legal support, COVID-19.

JEL Codes: K19, K23. Paper type: Research article.

\footnotetext{
${ }^{1}$ Professor of the Department of Linguistics and Foreign Languages, Deputy Director for Teaching and Educational Work, Candidate of Pedagogical Sciences, Associate Professor, Rostov branch of the Russian State University of Justice, Rostov-on-Don, zamuvr@inbox.ru; ${ }^{2}$ Senior lecturer, South-Russian Branch of The Russian Presidential Academy of National Economy and Public Administration, Rostov-on-Don, koroleva-sv@ ranepa.ru;

${ }^{3}$ Candidate of legal sciences, Associate Professor, Associate Professor state-legal disciplines, Rostov branch, the Russian state University of justice, Rostov-on-Don, uristika@ rambler.ru; ${ }^{4}$ Candidate of legal sciences, Associate Professor state-legal disciplines, South-Russian Branch of The Russian Presidential Academy of National Economy and Public Administration, Rostov-on-Don, L.keep_law@list.ru;

${ }^{5}$ Candidate of legal sciences, Associate Professor state-legal disciplines, South-Russian Branch of The Russian Presidential Academy of National Economy and Public Administration, Rostov-on-Don, millerovyEVEA@yandex.ru;

${ }^{6}$ Candidate of legal sciences, Associate Professor state-legal disciplines, Rostov branch of the Russian State University of Justice, Rostov, kavelinaolga@yandex.ru;
} 
658

\section{Introduction}

The effectiveness of state and municipal administration is determined by socioeconomic indicators, which are assessed both by the population and by state authorities. According to the Ministry of Economic Development of the Russian Federation, a slight slowdown in economic growth to $0.7 \%$ YoY is noticeable in 2019 compared to an increase of $2.3 \%$ YoY in 2018.

Figure 1. In the first half of 2019 PMI indices declined (MED RF, 2020)

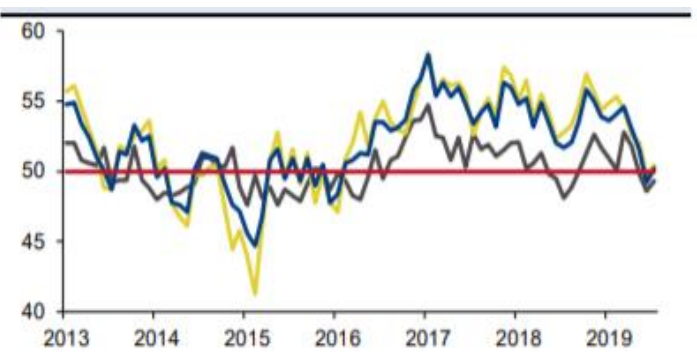

---- PMI: manufacturing PMI: services

---- PMI: composite

Source: Own study.

Figure 2. From the beginning of the year less new employees were required \%YY

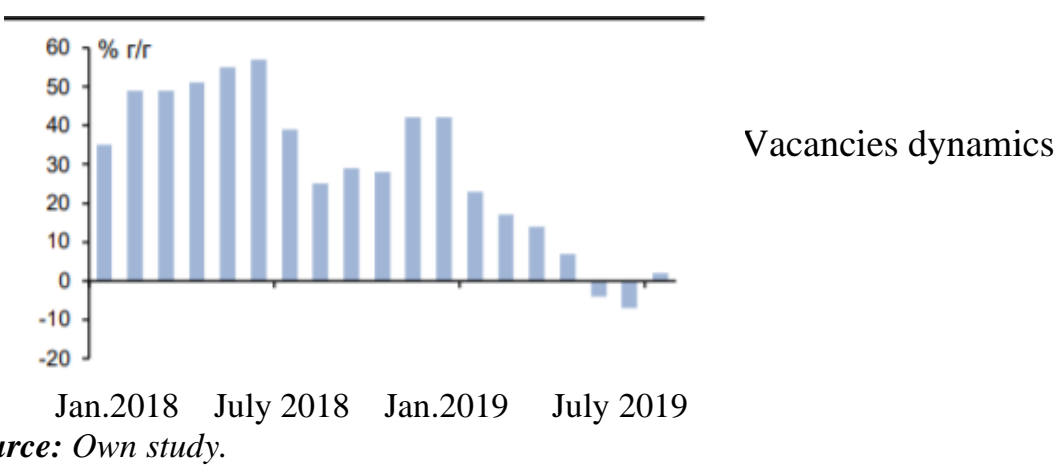

In this case, analysts identify a number of factors that affected the economic stability of our state. Maintaining balance, maintaining the economic system in a planned and predictable state is one of the important state tasks, implemented through the prism of the entire system of public administration in all spheres of social relations. One of the priorities of mobilizing the state efforts is to increase the efficiency of the professional training level for state and municipal employees using modern economic, organizational, communication, social, psychological and motivational mechanisms for managing civil and municipal service staff. 


\section{International Standards Governing Public Service Relations}

The Universal Declaration of Human Rights in article 21, part 2, enshrined the right of every person to equal access to civil public service (UDHR, 1948). Similar norms are introduced in the International Covenant on Civil and Political Rights (Adopted on December 16, 1966 by Resolution 2200 (XXI) at the 1496th plenary meeting of the UN General Assembly) in Article 25, which without any discrimination and unreasonable restrictions allow access on general terms to public service to all citizens. The principle of equal access to civil service is also enshrined in the African Charter on Human and Peoples' Rights (Article 13), the American Convention on Human Rights (Article 23).

Certain aspects of this principle are reflected in international legal acts concerning the equal rights of women and men when entering the civil public service (Article 7 of the Convention on the Elimination of All Forms of Discrimination against Women; Article 4 of the UN Declaration on the Elimination of Discrimination against Women); every person, without distinction of race, color, national or ethnic origin, on equal access to public service (Article 5 of the International Convention on the Elimination of All Forms of Racial Discrimination).

However, the documents of the Council of Europe, including the 1950 European Convention for the Protection of Human Rights and Fundamental Freedoms, do not contain any regulations that would enshrine the right of citizens to access public service. The countries that are members of the Council of Europe did not regulate this issue normatively, due to the fact that when administering justice, the European Court, when establishing uniform standards of recruitment, may face certain problems, since in different states the requirements for recruitment to the public service differ in accordance with national traditions and political systems influencing the public service (SHR, 2002).

Equal access for all citizens to civil service and the right to hold public office are declared in the constitutions of many European countries (Article 25 of the Constitution of the Principality of Andorra; Section 70 of the Constitution of the Republic of Hungary; Article 101 of the Constitution of the Republic of Latvia; Article 33 of the Constitution of the Republic of Lithuania; Article 31 Constitution of the Principality of Liechtenstein, Article 11 of the Constitution of the Grand Duchy of Luxembourg; Article 23 of the Constitution of the Republic of Macedonia; Article 3 of the Constitution of the Kingdom of the Netherlands; Article 60 of the Constitution of the Republic of Poland; Article 50 of the Constitution of the Portuguese Republic; Article 101 of the Constitution of the Republic of San Marino; Article 30 of the Constitution of the Slovak Republic; Art. 70 of the Constitution of the Republic of Turkey; Art. 33 of the Basic Law of the Federal Republic of Germany; Art. 44 of the Constitution of the Republic of Croatia, etc.) with certain features (Pchelintsev, 2009). 


\section{The Current National Legislation Analysis, Statistical Data and Results of Public Surveys on Improving Civil Servants Efficiency}

According to specialists from the Ministry of Economic Development of the Russian Federation, one of a number of additional measures to increase the potential for economic growth are:

$>$ increasing the functional efficiency of the state and quasi-state sectors: widespread labour productivity improvement culture through the technologies of "lean production", including "public administration" sector;

$>$ public administration system: full-scale implementation of project management principles, extension of the basic principles of national project management to the entire public administration system, digitalization of public administration system elements, including the decision-making process and the human capital development system (MED RF, 2020).

The public administration performance indicators are determined by certain criteria that are already generally known to the theory of social management.

This is a fairly well-known formula:

$$
\text { E - R / G, }
$$

where E - efficiency; P - result; G - goal.

Consequently, the goal $(\mathrm{G})$ can be changed depending on specific model criteria.

The effectiveness of a specific action is determined by a set of criteria taking into account a certain mode of decision-making and execution. It is a decision that is associated with the subject's functional load for the resource use which is costeffective and result-oriented. Most likely, the effectiveness of this type of managerial action should be determined by the "goal-result-interests" model or by the "costbenefit" criterion, on the basis of which resource allocation decisions are made.

The quality of public administration in Russia directly depends on the professional qualities of civil servants. However, Russian and international experts' conclusions, opinion polls' data, country's top leadership assessments indicate that the quality of public administration requires new innovative approaches to the methodology for assessing their effectiveness. So, according to The All-Russian Public Opinion Research Center (WCIOM, 2020), the respondents' answers to the question: Do you in general approve or disapprove of the activities of the President, Prime Minister, Government, etc. are presented as follows (VCIOM, 2020). Society demands regarding the state civil service which is to ensure the exercise of public authority and to regulate public relations professionally are growing. The contradiction between the increased demands of society for the civil service in a market economy and the low level of professionalism of civil servants, failure of motivational attitudes and professional qualities of civil servants to comply with these requirements are 
recognized as one of the acute social problems both by various political forces and by most Russians.

Table 1. Approval of State institutions activities

\begin{tabular}{|c|c|c|c|c|c|c|c|c|c|c|c|c|c|c|c|c|c|}
\hline $\begin{array}{l}\text { Do you in } \\
\text { general } \\
\text { approve or } \\
\text { disapprove } \\
\text { of the } \\
\text { activities of } \\
\ldots . . . ?\end{array}$ & 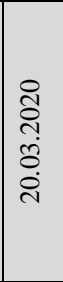 & 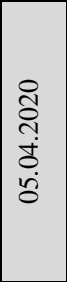 & 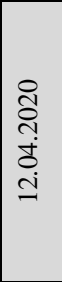 & $\begin{array}{l}\text { กิ } \\
\text { ते } \\
\stackrel{+}{0} \\
\stackrel{0}{0}\end{array}$ & 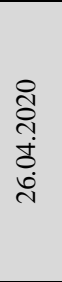 & 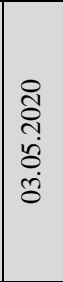 & $\begin{array}{l}\text { กิ } \\
\text { กิ } \\
\text { nุ } \\
0 \\
0\end{array}$ & 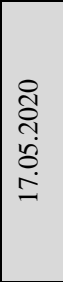 & 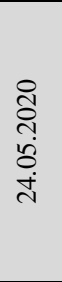 & 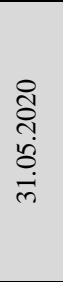 & 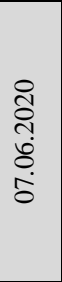 & 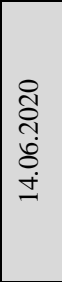 & 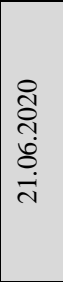 & 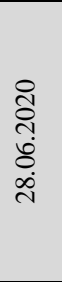 & 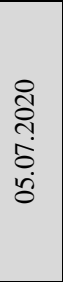 & 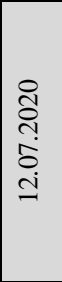 & 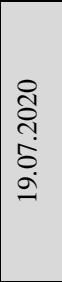 \\
\hline Approval & & & & & & & & & & & & & & & & & \\
\hline $\begin{array}{l}\text { President of } \\
\text { Russia }\end{array}$ & 65,7 & 68,6 & 65,1 & 64,7 & 62,2 & 62,1 & 61.0 & 62,8 & 65.0 & 62,3 & 61,2 & 62,4 & 63,3 & 64 & 64,2 & 63,6 & 61,2 \\
\hline Prime Minister & - & - & - & 38,9 & 37,8 & 39,2 & 37,4 & 37,1 & 39,5 & 38,5 & 38,3 & 38,9 & 40,2 & 39,4 & 40.0 & 38,8 & 39,0 \\
\hline $\begin{array}{l}\begin{array}{l}\text { Government } \\
\text { of RF }\end{array} \\
\end{array}$ & - & - & - & 38,9 & 37,7 & 38,4 & 36.0 & 36,5 & 37,7 & 36,2 & 35,9 & 36,6 & 37.0 & 38,4 & 38,4 & 36,2 & 36,4 \\
\hline Disapproval & & & & & & & & & & & & & & & & & \\
\hline \begin{tabular}{|ll}
$\begin{array}{l}\text { President of } \\
\text { Russia }\end{array}$ \\
\end{tabular} & 24.7 & 22.4 & 24.8 & 25.5 & 27.8 & 28.5 & 29.2 & 27.9 & 27.2 & 28.2 & 29.7 & 28.3 & 28.1 & 26.3 & 26.6 & 27.5 & 29.7 \\
\hline \begin{tabular}{|l|} 
Prime \\
Minister
\end{tabular} & - & - & - & 8.3 & 9.9 & 11.0 & 10.5 & 10.6 & 11.4 & 12.2 & 12.3 & 11.4 & 11.6 & 11.4 & 44.6 & 11.3 & 12.1 \\
\hline $\begin{array}{l}\text { Government } \\
\text { of RF }\end{array}$ & - & - & - & 23.3 & 25.0 & 25.5 & 26.6 & 27.3 & 27.1 & 27.3 & 27.9 & 26.1 & 26.9 & 26.1 & 25.9 & 25.7 & 27.5 \\
\hline $\begin{array}{l}\text { Index (Index = } \\
\text { Approval- } \\
\text { Disapproval) }\end{array}$ & & & & & & & & & & & & & & & & & \\
\hline $\begin{array}{|lr|}\begin{array}{l}\text { President of } \\
\text { Russia }\end{array} \\
\end{array}$ & 41 & 46 & 40 & 39 & 34 & 34 & 32 & 35 & 38 & 34 & 32 & 34 & 35 & 39 & 38 & 36 & 32 \\
\hline Prime Minister & & & & 31 & 28 & 28 & 27 & 27 & 28 & 26 & 26 & 28 & 29 & 28 & 28 & 28 & 27 \\
\hline $\begin{array}{l}\text { Governme } \\
\text { nt of } R F\end{array}$ & & & & 16 & 13 & 13 & 9 & 9 & 11 & 9 & 8 & 11 & 10 & 12 & 13 & 11 & 9 \\
\hline
\end{tabular}

Source: Own study.

Figure 3. Approval of State institutions activities

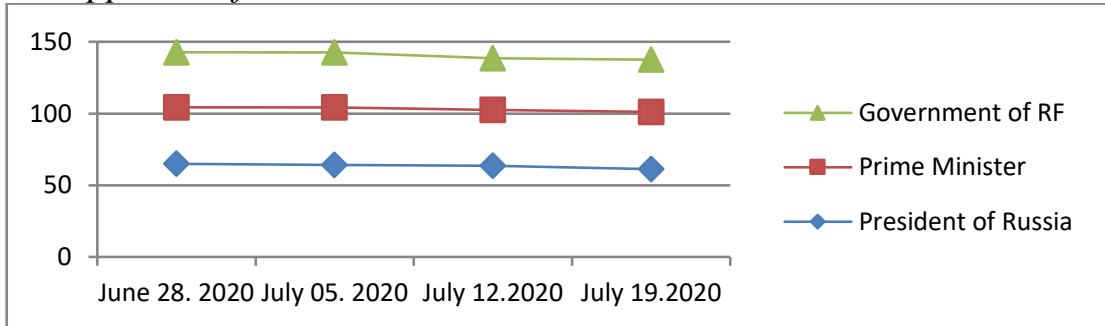

Source: Own study.

In the modern world, the inevitable modernization of state priorities is possible but only in case of adequate changes of civil servants' professional qualities. It determines the need for a comprehensive analysis of civil servants professional development as well as for theoretical grounds of innovative approaches to the technological development of their professional qualities. Currently, there is no systematic 
managerial and legal analysis of the modeling technologies practice for the development of civil servants professional qualities in civil service research.

The foreign experience of civil servants professional development was analyzed, as well as the best practices were identified and the possibility of their use in modern Russia was assessed. These practices include assessment centers, crowdsourcing, foresight, training and advanced training programs, knowledge and competence management. Unfortunately, today in our country such practices are not developing as rapidly as in most foreign countries, and there are many problems that need to be addressed. The problems of legal support for these activities are of special concern.

The current socio-economic and political situation has demonstrated the need for new criteria of civil servants professional development. Only few years ago professional development was limited to advanced training and additional education, but today this is clearly not enough. Considerable attention should be paid to the competitive selection methodology for evaluating candidates taking civil service posts.

The immediate supervisor or, on his behalf, his deputy is responsible for approving the results of passing the test for the civil service. No later than 14 working days after the test the required fixed format feedback is given, which takes into account the data of the table for recording the results of the civil servant's official duties performance during the trial period,as well as draft documents prepared by the civil servant, on which there are direct supervisor's comments, feedback on the mentoring results.

\begin{tabular}{|c|c|c|c|}
\hline $\begin{array}{c}\text { Date (period) of } \\
\text { task fulfillment }\end{array}$ & main tasks & $\begin{array}{c}\text { Completion mark (done, done } \\
\text { with comments, not done - } \\
\text { specify the necessary one) }\end{array}$ & $\begin{array}{c}\text { direct supervisor's } \\
\text { commentaries (if } \\
\text { any) }\end{array}$ \\
\hline
\end{tabular}

In case the test passed successfully, the feedback on the test results may include, if necessary, a recommendation to send the civil servant to participate in professional development activities. If the test result is unsatisfactory, the feedback on the test results shall indicate the reasons that served as the basis for recognizing the civil servant as having failed the test. The normative legal acts state that a civil servant should have "the required professional qualities and competence." At the same time, not a single regulatory legal act defines what it is, thereby leaving an opportunity for a subjective assessment of civil servants.

In our opinion, the category "required professional qualities" should include a set of general cultural, informational, communicative qualities. But in practice difficulties may arise in assessing these qualities as well. It is due to the fact that neither the criteria for these qualities evaluation, nor their amount are legally defined. That is, there are no specific instructions on what kind of general cultural qualities a particular official should have. 
An indicator of a civil servant's professionalism will be the efficiency of his service. These are two related categories. The higher is the efficiency of a civil servant's activities, the higher is his professionalism. It should be noted that the problem of the civil service staff professionalism is very relevant not only in Russia. This is primarily due to the very rapid informational development of society. Of course, the education of employees plays an important role in public administration, as well as in commercial organizations (Semykina and Vorontsova, 2015).

The Russian legislation defined the state civil service. Its main feature is professional service activity on the basis of special knowledge, skills and abilities. Of course, if government civil servants possess a high level of professionalism, then the duties effectiveness will also increase.

Besides the civil servants compliance with the civil service qualification requirements, their professional, cultural and moral qualities should be high. In terms of enforcement there is a big gap as all of these categories are very abstract and remain purely subjective. The current legislation lacks the category of "professionalism", which often leads to a distortion of this concept. At the same time, professionalism is constantly mentioned in any acts, ranging from state civil servants official regulations to federal regulatory legal acts.

From the point of view of legislation, professionalism assessment is also a very abstract category. There is no clear mechanism for such an assessment in any regulatory legal act. It turns out that citizens can assess state civil servants activities. But it might be problematic as well, since citizens can judge civil servants according to the results of public services provided, but after all, not all civil servants provide public services. And thus, it turns out that those officials whose duties according to the official regulations are not supposed to be related to public services cannot be evaluated and it is impossible to determine the level of their professionalism. Such approach is fundamentally wrong. On the other hand, if the procedure for assessing professionalism is reduced to the staff performance appraisal only, it won't reflect the meaning and all the components of the category of professionalism.

Civil servants' professionalism assessment is associated with personal and professional assessment. We believe it is possible to introduce a comprehensive assessment of civil servants professional competencies into the public administration practice. At the same time, this mechanism needs to be enshrined at the federal level as the duty of state authorities to be engaged in these activities. This is an objective necessity in order to exclude the possibility of carrying out these activities at their own discretion. Today civil servants must be ready for new challenges, respond promptly, adapt to new trends and innovative development.

The situation happened in the spring of 2020 in connection with the pandemic caused by the new coronavirus infection COVID-19, made it possible to identify the strengths and weaknesses of the public administration system. Of course, in general, Russia has 
shown a very strong result in the fight against coronavirus. The public administration system worked to forestall possible dire consequences. Russian President V.V. Putin said that "Russia has resources and potential for anti-crisis policy in a pandemic, they need to be used as efficiently as possible" (TASS, 2020).

In general, the pandemic is a serious challenge even not so much for the business community as for the public administration system. It is civil servants that must heed the high expectations of the society today about effective and fast response measures. One cannot but admit the fact that the state apparatus has been working in extreme conditions for all this time, when decisions are to be made at lightning-fast speed, resorting to extremely harsh measures sometimes. In such conditions the professionalism of civil servants was required more than ever. The current conditions demanded "out of the blue" actions, regardless the previously adopted practices. The world faced such a situation for the first time and programs had to be developed and adopted literally on the go. In the current environment, like never before. All the weaknesses in the civil servants training were clearly identified.

We believe that when conducting a personal assessment of civil servants, the respondent's readiness to work in stressful situations and the ability to make decisions quickly are always determined. It was these indicators that turned out to be extremely important when working in a pandemic, when it was necessary to restructure the work of the state apparatus completely.

The need to train civil servants to work online turned out to be extremely important, though it was difficult even to imagine such a format of work for public authorities until the spring of 2020. Innovative area of professional development for officials' training is one of the main current needs of the state apparatus. The pandemic has shown that many state civil servants are simply not ready to work in stressful situations, as well as to the new format. In such conditions, it is impossible to perform their duties professionally.

In this regard, it is appropriate to mention the upcoming amendments to the Article 66 FZ-79, concerning the development of the civil service, which will allow experiments on the use of new approaches to the civil service organization and changes the terms of contracts, respectively, new additional performance criteria such as mobility, skill and quality of online work, are likely to be introduced. It should be noted that for the effective management of the state civil service personnel as well as for the successful development of the public administration system as a whole, constant training of HR managers and employees of public authorities is necessary.

The civil servants professionalism influences the prestige of civil service as well. Today, the objective need of society for professionals in various fields is an important factor of the development of civil servants professionalism. 
Historically, special requirements are always imposed on officials. The population wants to see civil servants as professionals in all spheres, who are ready to solve any problem as quickly and effectively - that is even more important - as possible. In fact the requirements for civil servants are much higher than those for applicants or employees in commercial companies. It may be explained by the fact that the image and significance of the very sphere in which the civil servant works, its prestige play an important role. The higher the prestige of the profession, the higher the motivation for success and professionalism (Vorontsova and Kovaleva, 2015).

The professionalism of civil servants and their professional development are inextricably interconnected. High level professionalism should be in constantly developed and polished. Moreover, professional development is a broader category than professionalism. The level of civil servants professionalism depends on their professional development. Professional development can be viewed both as a process and as a result. At the same time, one cannot but pay attention to the fact that the activities of the public authorities HR services and the effectiveness of the personnel policy in general also reflect the professionalism of public administration. The professional development of civil servants today is a legally enshrined obligation.

We believe it is possible to propose the main directions for improving the professionalism of civil servants. The introduction of strategic planning into the practice of public administration will be extremely relevant. This implies the constant development of civil servants, increasing professionalism and competence, in order to create a whole corps of trained, highly qualified specialists who could increase the efficiency of the entire public administration. Here it is necessary to create an effective system for planning the needs for civil servants.

Another area of activity for increasing the level of civil servants professionalism is the creation of a system for attracting young specialists in order to strengthen the government bodies' HR potential

\section{Conclusion}

To improve the efficiency of assessing the civil servants professionalism, we believe it is possible to propose the following measures:

$>$ improving the system of personnel training and additional professional education of civil servants;

$>$ introduction of programs for the government civil servants' professional development and that of individual plans for the professional development of civil servants;

$>$ management of civil servants' professional qualities development;

$>$ creation of conditions for a planned sustainable career growth of civil servants who flawlessly and efficiently perform their duties with the purpose of the systematic renewal and rotation of civil service personnel; 
666

$>$ development of a system of career growth motivation for the civil servants;

$>$ introducing regulations into the practice of state bodies HR activity according to which the continued irreproachable and effective performance by state officials of their duties must be taken into account when they are appointed to a higher post, awarded a superior grade or promoted;

$>$ introduction of strategic personnel planning mechanisms in the civil service.

The professionalism of the entire civil service, its authority in the society, largely depends on the quality of training and competence of civil servants, their conscientious attitude to official duties.

\section{References:}

ICCRP. 1966. International Covenant on Civil and Political Rights. Adopted on December 16, 1966 by Resolution 2200 (XXI) at the 1496th plenary meeting of the UN General Assembly.

Koroleva, S.V. 2013. Legal basis for increasing the prestige of the state civil service. Gaps in Russian legislation, 5, 256-258.

MED RF. 2020. File base of Ministry of Economic Development of the Russian Federation. Available at: https://www.economy.gov.ru/material/file.

Pchelintsev, S.S. 2009. International legal acts and the Constitution of foreign states on public service: a comparative analysis. Bulletin of RUDN, Series: Legal Sciences, 1.

Semykina, I.V., Vorontsova, G.V. 2015. On the formation of organizational structures in state and municipal government bodies. Modern trends in the development of theory and practice of management in Russia and abroad: proceedings of the IV (IX) International Scientific and Practical Conference, Stavropol, 165-167.

SHR. 2002. Council of Europe standards in the field of human rights in relation to the provisions of the Constitution of the Russian Federation. Moscow, Institute of Law and Public Policy.

TASS. 2020. The coronavirus pandemic should not shock the public administration system. Available at: https://tass.ru/politika/8239705.

UDHR. 1948. Universal Declaration of Human Rights. Adopted by the UN General Assembly on December 10.

VCIOM. 2020. Material of the Russian Public Research Center. Available at: https://wciom.ru/news.

Vorontsova G.V., Kovaleva A.A. 2015. Competitiveness of territories. Bulletin of the NorthCaucasian Institute of Humanities, 1(13), 9-16.

Yudanova, D.M. 2013. Problems of reforming the institute of public service of the Russian Federation. Economy, state, society, 2, 219-221. 